\title{
外来がん患者に対する薬剤師外来の役割とその評価
}

\author{
中島輝一 ${ }^{1,2}$, 真野泰成 ${ }^{2,3}$, 大内かお $り^{3}$, 佐藤大輔 ${ }^{4}$, 岩田杏子 ${ }^{1}$ \\ 樋口安耶 ${ }^{3}$, 江原邦明 ${ }^{3}$, 加藤芳徳 ${ }^{3}$, 廣澤伊織 ${ }^{3}$, 田島正教 ${ }^{3}$ \\ 土屋文人 ${ }^{1,3}$ ，山田治美 ${ }^{2,3}$ ，小瀧 - ${ }^{2,3}$ ，旭 満里子 ${ }^{2,3}$ \\ 国際医療福祉大学三田病院薬剂部 ${ }^{1}$, 国際医療福祉大学大学院薬科学研究科 ${ }^{2}$ \\ 国際医療福祉大学薬学部 ${ }^{3}$, 順江会江藤病院薬剤部 ${ }^{4}$
}

\section{Role of Pharmaceutical Outpatient Clinic in Cancer Patients and Evaluation}

\author{
Kiichi Nakajima, ${ }^{1,2}$, Yasunari Mano*2, ${ }^{3}$, Kaori Ohuchi ${ }^{3}$, Daisuke Sato ${ }^{4}$, Kyoko Iwata ${ }^{1}$, \\ Aya Higuchi ${ }^{3}$, Kuniaki Ebara ${ }^{3}$, Yoshinori Kato ${ }^{3}$, Iori Hirosawa ${ }^{3}$, Masataka Tajima ${ }^{3}$, \\ Fumito Tsuchiya ${ }^{1,3}$, Harumi Yamada ${ }^{2,3}$, Hajime Kotaki ${ }^{2,3}$ and Mariko Asahi ${ }^{2,3}$ \\ Department of Pharmacy, International University of Health and Welfare Mita Hospital, \\ Graduate School of Pharmaceutical Sciences, International University of Health and Welfare, \\ School of Pharmaceutical Sciences, International University of Health and Welfare, \\ Department of Pharmacy, Koto Hospital ${ }^{4}$ \\ $\left[\begin{array}{l}\text { Received February 13, } 2012 \\ \text { Accepted July 20,2012 }\end{array}\right]$
}

We established a pharmaceutical outpatient clinic at the International University of Health and Welfare Mita Hospital. In the clinic, pharmacists provide mainly pharmaceutical care for cancer outpatients based on prescriptions from a doctor, and then feed back the contents of medication counseling and information about patients to doctors.

In this study, we evaluated the role of the pharmaceutical outpatient clinic. From April to July 2011, we investigated retrospectively the contents of feedback from pharmacists to doctors. The contents consisted of three types of information such as medication counseling, history of side effects and allergy, and uneasiness from patients. Most of this information was on side effects. Approximately $42 \%$ of uneasiness from patients was about the side effects of chemotherapy. Furthermore, we conducted a questionnaire survey in 62 cancer outpatients that gave informed consent during the period as mentioned above. The results showed that the degree of understanding of drugs on treatment and prevention of the onset of side effects after consultation was markedly improved compared with those before consulting. Many patients (50/62) felt "uneasiness about treatment" and "some uneasiness" before consultation. However, 88.0\% $(44 / 50)$ of them noted that their "anxiety was eased" after consultation. The degree of reduction in uneasiness in patients with stage I and II breast cancer was larger than that with stage III and IV. In conclusion, it is suggested that the clinic may play a role which makes it possible to enable cancer outpatients to participate in medical treatment with ease, in addition to enabling support for doctors.

Key words — pharmaceutical outpatient clinic, cancer chemotherapy, pharmaceutical care, oral anticancer agent, medication counseling, side effect

\section{緒言}

「患者中心」としたチーム医療が重視されるよ うになり, 病院薬凨師は 1988 年より入院患者を 対象とした服薬指導や薬剂管理指導を実施してき
た。 また，外来患者に対しては，院外処方せん発 行率が増加し, 薬局薬剤師による服薬指導が定着 してきている。しかし，経口抗凝固薬ワルファリ ンによる薬物治療モニタリング，喘息患者の吸入 指導やがん化学療法に対する治療支援など, 医師

*栃木県大田原市北金丸2600-1 
への迅速なフィードバック（情報提供）を必要と する領域においては, 外来患者に対する病院薬剤 師の関与が求められている.

このような背景の中, 病院内に「薬剤師外来」 を設置する施設が増えている。薬郕師外来は，薬 剂師が外来患者の薬物療法上の問題点を抽出し, 患者の状況に適した服薬指導や薬剤管理指導を行 うことにより，医師への薬物療法の支援および外 来患者の薬物療法の質の向上を目的としている. 我が国では，海外の実例を参考に名古屋大学病院 が, ワルファリンによる薬物治療モニタリングゃ 喘息患者の吸入指導などを行う「薬剤師外来」を 先進的に展開してきた. ${ }^{1,2}$ 現在, その概念が他施 設にも導入され始めている.

一方，近年，がん患者の治療は外来で行われる ことが多くなり，通院治療患者の割合は 2002 年の 46.2\%から 2008 年は 52.5\%に増加している（http:// www.mhlw.go.jp/toukei/saikin/hw/hoken/kiso/21. $\mathrm{html}$ : 厚生労働省平成 21 年地域保健医療基礎統 計). 外来がん化学療法室での治療が普及するに伴 い，多くの施設では，注射薬抗がん剂に対して薬 剂師の服薬指導を受ける体制が整っている。しか し, 内服薬抗がん剤については, 薬剤師による服 薬指導を受ける機会が少ないのが現状である.

国際医療福祉大学三田病院（以下, 当院）では, 2010 年 2 月に「薬剤師外来」を開設した。薬剤 師外来開設以来, 外来がん患者に対しては, 注射
薬および内服薬全ての抗がん剤を対象に薬剤管理 指導を行っている.

しかし，外来がん患者に対する「薬剤師外来」 の取り組みについては, 今村ら ${ }^{3)}$ や前ら ${ }^{4)}$ の報告 があるが，注射薬および内服薬全ての抗がん剂を 対象とした薬剤師外来の有用性に関する報告は少 ない.

そこで, 本研究では, 当院薬郕師外来を受診し た外来がん患者を対象に，(1薬剤師から医師への フィードバック内容を解析するとともに, (2)患者 の治療薬剤に対する理解度や不安についての調査 を行い, 当院における薬剤師外来の役割について 評価を行った。

\section{方 法}

\section{1. 外来がん患者に対する薬剤師外来の運用}

（1）薬剤師外来の指導体制（指導内容および医師 へのフィードバック）

当院の薬剂師外来は，外来部門に専用の部屋が 設置されており, 薬剂師 6 名（調剤業務, 病棟業 務兼務）で実施している，運用方法は，まず，医 師が診察終了後に, 薬剤師の指導を必要と判断し た場合，薬剤師外来宛てに指導依頼書を提出する (図 1 および図 2A)，薬剤師はその指導依頼書を受 けて，初めて抗がん剤治療を予定している患者， または抗がん剂治療が変更（レジメン変更）になっ

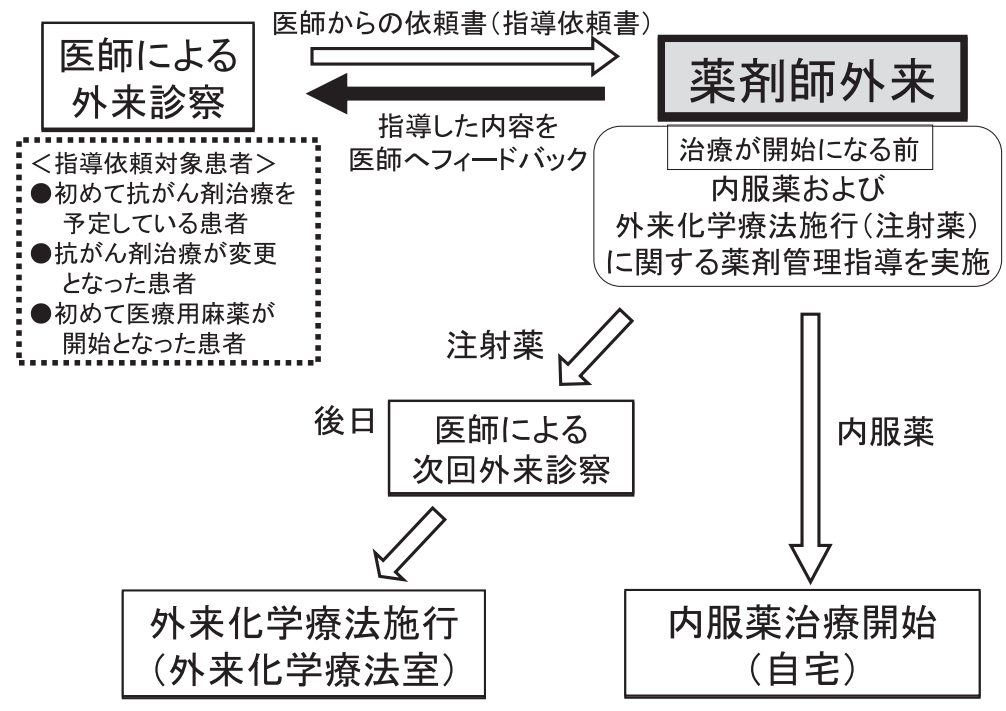

図1 国際医療福祉大学三田病院における「薬剤師外来」受診の動線 


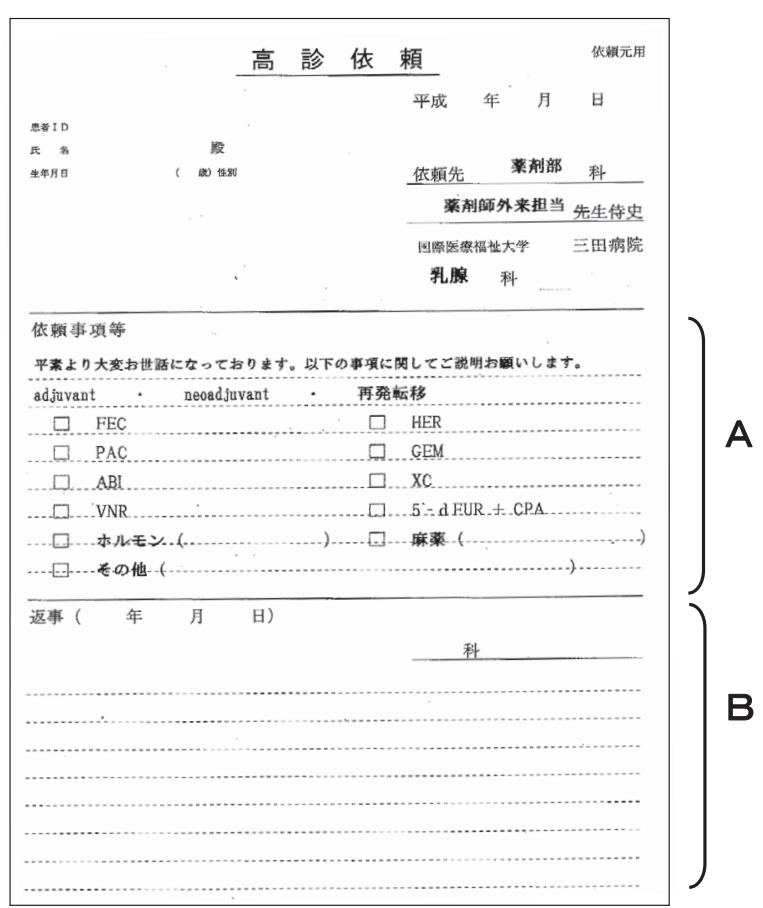

図 2 指導依頼書 (高診依頼書) A：医師から薬剂師外来への依頼事項 B：薬剤師から医師へのフィードバック内容

た患者，初めて医療用麻薬が開始となった患者に 対して, 治療開始前に面談形式で指導を行う。指 導に要する時間は, 1 患者あたり約 20～30分である. 担当薬剂師間での指導内容の統一を図るために, 薬剤師外来指導用マニュアルを作成するとともに, パンフレット（製薬会社作成）を用いて指導を行う. 指導内容は, 薬剤の効能 - 効果, 服用方法 - 投与 スケジュール，副作用の種類とその対策，および 日常生活での注意点などである。レジメンが変更 になった患者に対しては，過去の抗がん剂治療に おける副作用発現状況の確認を行う。また，抗が ん剤と同時に支持薬や医療用麻薬についても指導 を行う。指導後, 薬剤師による指導内容や過去の 治療歴に関する患者情報（副作用歴・アレルギー 歴など）抢よび患者からの不安・訴えなどを，医 師へフィードバック（情報提供）する（図 2B）.

\section{（2）指導依頼件数の実績調査}

薬剤師外来を開設した 2010 年 2 月～2011 年 9 月の 1 年 8 力月間に㧍ける薬剤師外来への外来が 几患者指導依頼件数を調查した，医師からの指導 依頼書を基に，診療科別に月ごとに指導依頼件数 を集計した。

\section{2. 薬浏師から医師へのフィードバック内容の 解析}

対象患者は, 2011 年 4 月 1 日〜 7 月 31 日の 4 力 月間に薬剤師外来を受診した外来がん患者とし た．指導依頼書から, 薬剤師外来への依頼事項(依 頼薬剂）抢よび，薬剤師から医師へのフィードッ ク内容をレトロスペクティブに調査した。医師へ のフィードバック内容は「患者への服薬指導内 容」,「過去の治療歴に関する患者情報提供（副作 用，アレルギー歴など)」，および「患者からの不 安・訴えに関する情報提供」に分類した。

\section{3. 治療薬剤の理解度や患者の不安および薬剤師 外来の感想についての調査}

(1) アンケートによる調査

対象患者は, 2011 年 4 月 1 日〜 7 月 31 日の 4 力 月間に薬剂師外来を受診し, 本調査についての同 意が得られた外来がん患者とした。薬剤師外来受 診の前後でアンケートを 2 回行った. 薬剤師外来 受診前アンケートについては, 薬剤師外来受診前 の待ち時間を利用し記入を依頼した。薬剤師外来 受診後アンケートについては, 次回来院時までに アンケートの記入を依頼した，患者背景は, 当院 のカルテおよびオーダーリングシステム等から抽 出し，氏名をマスクしたうえで解析した。

アンケートは,「治療薬剤に対する理解度」と「治 療に対する患者の不安」に関する内容で, 前者は, 「治療薬剤の理解」,「服用の重要性と投与スケ ジュールの理解」および「副作用の発現や予防法 の理解」の 3 項目とし, 後者は, 薬剤師外来受診 前では「治療に対する不安がありますか」, 受診 後では「治療に対する不安や精神面に変化があり ましたか」とした，各設問について薬荗師外来受 診前後で比較検討した。統計解析は Wilcoxon signed-rank test を用い, 有意水準は $P<0.05$ とし た. さらに, 薬剤師外来受診についての患者の感 想を把握するために，「医師に聞きたいことは言 えていると思いますか」,「薬片師外来を受診して どうでしたか」および「今後も薬剤師外来を受診 したいですか」の項目を設けた.

（2）スコア化による不安軽減度の解析

薬片師外来受診前アンケートにおいて, 治療に 
対して「不安ある」および「不安少しある」と回 答した患者を対象に, 薬剂師外来受診後の不安軽 減度について解析した。薬剤師外来受診後の不安 軽減度については「軽減した：2」,「少し軽減した： $1 」$,「変わらない：0」,「少し不安になった：-1」 および「不安になった：-2」とスコア化し，患者 背景別に分類して，解析した．がん種については， 乳がんと頭頸部がんの 2 群に分けた。さらに，乳 がん患者については，がん進行度別および薬剤師 外来受診回数別に分類し，解析した．がん進行度 については福江らの報告 ${ }^{5)}$ に基づき上記乳がん患 者をステージ I ・ II と III・IVに, 薬剤師外来受診 回数については同じく乳がん患者を対象に 1 回と 2 回以上の 2 群に分けた。統計解析は MannWhitney $U$ test を用い, 有意水準は $P<0.05$ とした。

なお，本研究は国際医療福祉大学三田病院倫理 委員会の承認を得ている。

\section{結果}

\section{1. 外来がん患者に対する薬剤師外来の運用結果 （指導依頼件数）}

2010 年 2 月～2011 年 9 月の薬片師外来におけ る外来がん患者の指導依頼件数の合計は 301 件で あった（図 3）。頭頸部腫瘍センターからの依頼 件数は 131 件であり, 2010 年 10 月より開始となっ た乳腺センターからの依頼は 170 件であった。 な お，乳腺センターと頭頸部腫瘍センターでは，指
導依頼対象患者は, 約 100\%薬剤師外来へ依頼が あった。

\section{2. 薬剤師から医師へのフィードバック内容の 解析}

（1）依頼事項（依頼薬剤）の内訳

2011 年 4 月〜 7 月の調査期間内に薬剂師外来を 受診した外来がん患者は 111 名（男性 27 名およ び女性 84 名）であった。がん種別では乳がん患 者が 74 名, 頭頸部がん患者が 37 名で, 年齢は $58.3 \pm 13.5$ 歳（平均值 \pm 標準誤差）であった。

医師から薬殽師外来への依頼事項を図4に示す。 調查期間における依頼件数は，のべ 127 件であっ た。 その内訳は乳腺センターからの依頼が 77 件, 頭頸部腫瘍センターからの依頼が 50 件であった. 依頼事項は，抗がん剂（レジメン）が 112 件で全 体の $88.2 \%$ であった．麻薬に関する依頼件数は 9 件，その他が 6 件であった．乳腺センターからの 依頼で最も多かったのは, リュープロレリン酢酸 塩注+タモキシフェンクエン酸塩錠が 10 件, 頭頸 部腫瘍センターからの依頼では, S-1（テガフール . ギメラシル・オテラシル配合）カプセルが 30 件と 最も多かった。依頼された抗がん剤の内訳は, 内 服薬（内服薬単剤, 注射薬との併用療法含む）が 60.6\%であり, 注射薬の $42.5 \%$ に比べ多かった.

(2) 医師へのフィードバック内容の内訳 医師へのフィードバック内容の内訳を図 5 に 示す.「患者への服薬指導内容」は, 対象患者

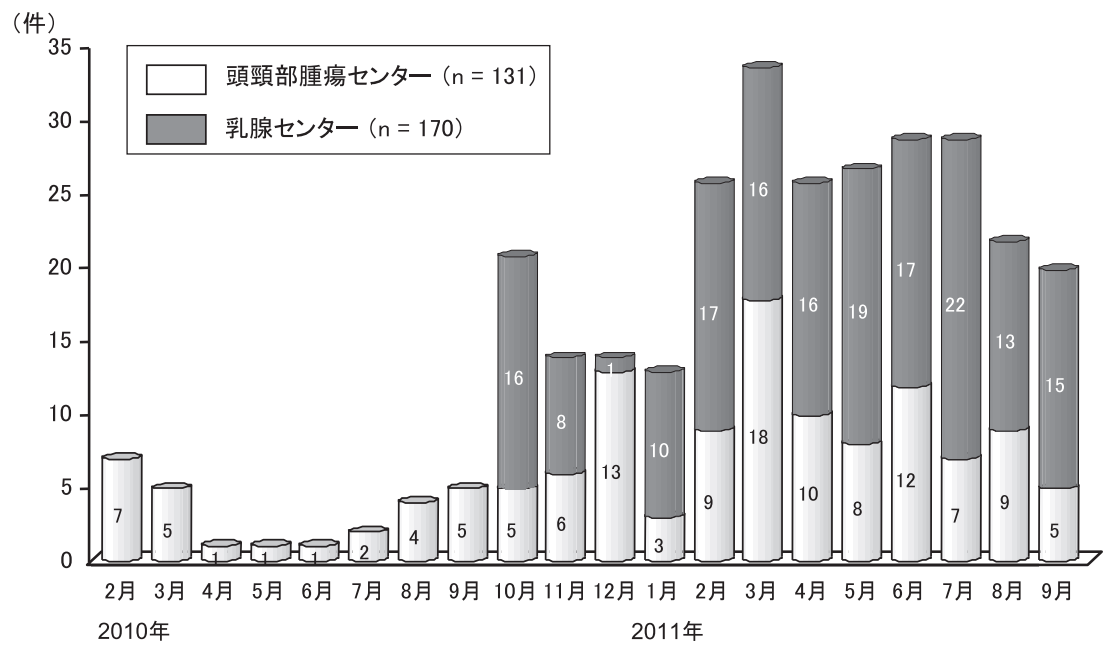

図 3 薬剤師外来における外来がん患者の指導依頼件数 


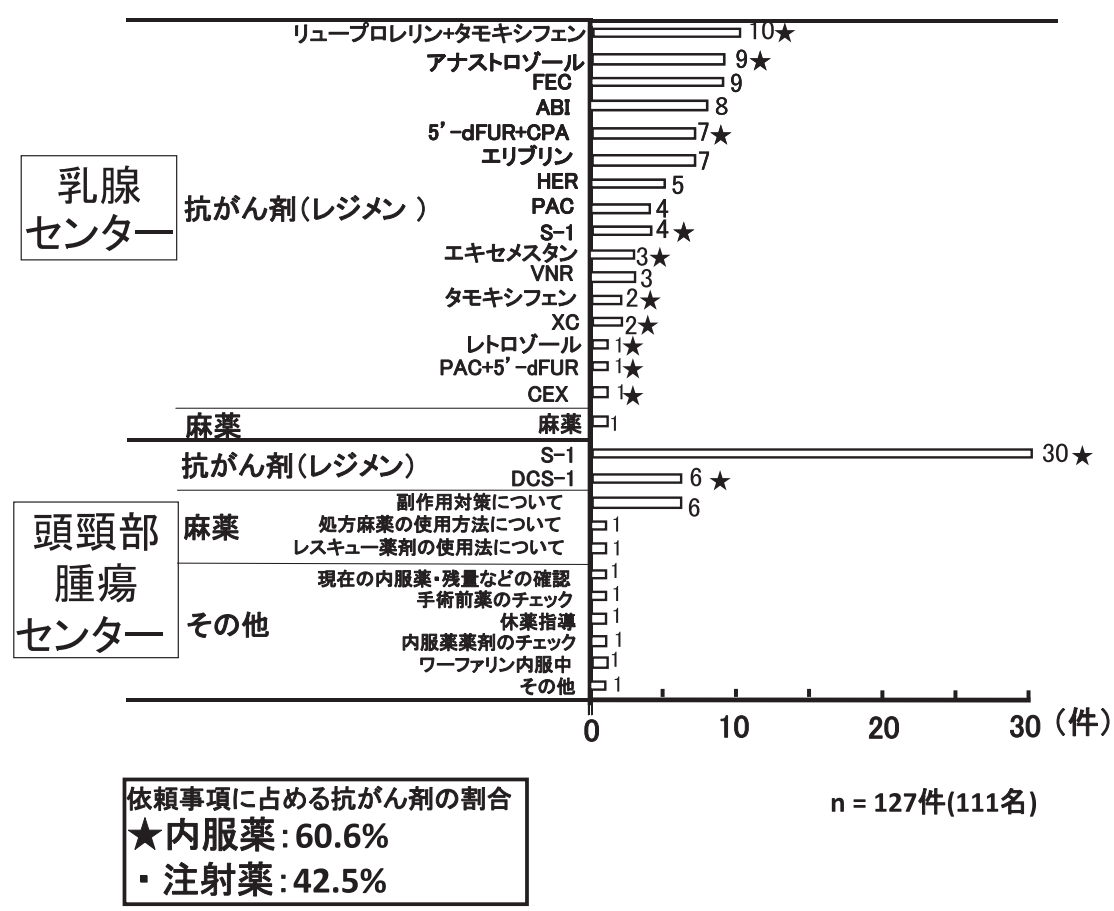

図 4 医師からの薬剤師外来への依頼事項

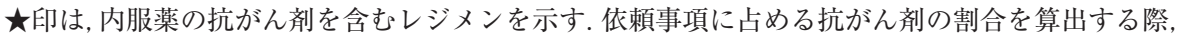

CEXのような内服薬と注射薬が併用されるレジメンでは, 各々カウントして算出した.

以下に略語の説明を示す。

$\mathrm{ABI}$ ：アルブミン懸濁型パクリタキセル注, CEX : エピルビシン注+シクロホスファミド注カカペシタビン錠

DCS-1：ドセタキセル注＋シスプラチン注＋S-1 カプセル，5'-dFUR + CPA：ドキシフルリジンカプセル＋シクロホスファミド錠

FEC : エピルビシン注+シクロホスファミド注+フルオロウラシル注, HER : トラスッズマブ注, PAC: パクリタキセル注

PAC+5'-dFUR：パクリタキセル注+ドキシフルリジンカプセル，S-1：テガフール・ギメラシル・オテラシル配合カプセル

VNR：ナベルビン注, XC：カペシタビン錠+シクロホスファミド錠

111 名全員に行っており，フィードバック率は 100\%であった。「過去の治療歴に関する患者情報 提供」は 111 名中 64 名に行っており $57.7 \%$ およ び「患者からの不安・訴えに関する情報提供」は 111 名中 37 名に行っており $33.3 \%$ であった。

表 1 に薬剤師が医師に対してフィードバック を行った「患者への服薬指導内容」の内訳を示す. 服薬指導内容を分類すると，「副作用」が $66.4 \%$ であり，「薬歴・アドヒアランス」が $41.9 \%$ お よ び「治療」が $23.3 \%$ であた。副作用の分類の内 訳は，「副作用の種類」が $82.9 \%$ と最も多く, つ いで「副作用とその対策」 $64.9 \%$,「薬での副作用, アレルギー歴の確認」51.4\%の順であった。

表 2 に薬剂師が医師に対してフィードバック を行った「過去の治療歴に関する患者情報提供」 の内訳を示す．過去の治療歴に関する患者情報提 供の件数は 100 件であり，それを分類すると，「副 作用に関する情報」が 76 件と最も多く,ついで「治 療薬に関する情報」 14 件,「その他患者情報」10

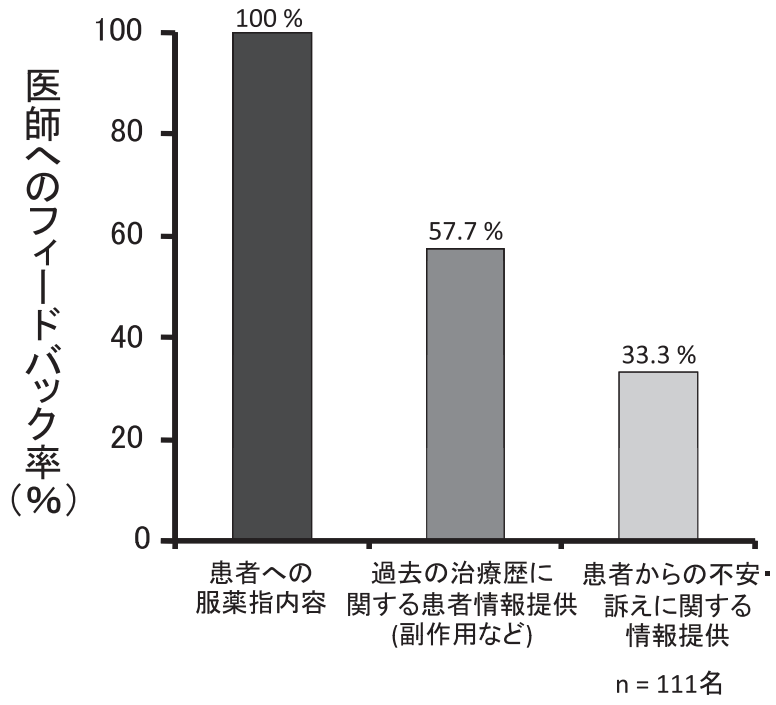

図 5 医師へのフィードバック内容の内訳 医師へのフィードバック率（\%）は，次式にて算出した。 医師へのフィードバック率 $(\%)=$ $\frac{\text { 各項目において薬剤師が医師へフィードバックした人数 }}{\text { 対象患者 }(111 \text { 名 })} \times 100$

件の順であった「副作用に関する情報」につい ては, 過去の治療時における悪心・嘔吐や末梢神 
表 1 薬剤師が医師に対してフィードバックを行った「患者への服薬指導内容」の内訳 $\mathrm{n}=111$ 名

\begin{tabular}{|c|c|c|c|}
\hline 分類 & 項目 & 割合* $(\%)$ & 平均 $(\%)$ \\
\hline \multirow{3}{*}{ 副作用 } & 副作用の種類 & 82.9 & \multirow{3}{*}{66.4} \\
\hline & 副作用とその対策 & 64.9 & \\
\hline & 薬での副作用, アレルギー歴の確認 & 51.4 & \\
\hline \multirow{5}{*}{$\begin{array}{c}\text { 薬歴・ } \\
\text { アドヒアランス }\end{array}$} & 服薬指導の理解度確認 & 91.0 & \multirow{5}{*}{41.9} \\
\hline & 飲み忘れたときの説明 & 36.9 & \\
\hline & アドヒアランス・コンプライアンスの確認 & 28.8 & \\
\hline & その他の内服薬の確認 & 10.8 & \\
\hline & 過去の服用歴 ～～～～～～～～ & 6.3 & \\
\hline \multirow{8}{*}{ 治療 } & 用法・用量 & 64.0 & \multirow{8}{*}{23.3} \\
\hline & スケジュール & 45.0 & \\
\hline & 作用・効能効果 & 45.0 & \\
\hline & 患者への注意事項など & 18.9 & \\
\hline & 感染症予防 & 9.0 & \\
\hline & 手術前の中止薬の確認 & 1.8 & \\
\hline & 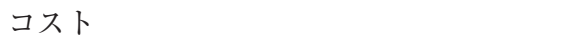 & 1.8 & \\
\hline & 日常生活の注意点 & 0.9 & \\
\hline
\end{tabular}

*各項目の割合は，次式にて算出した。

各項目の割合 $(\%)=\frac{\text { 薬剤師により各項目を説明した患者数 }}{\text { 対象患者 }(111 \text { 名 })} \times 100$

表 2 薬剤師が医師に対してフィードバックを行った「過去の治療歴に関す る患者情報提供」の内訳 $\mathrm{n}=100$ 件（64 名）

\begin{tabular}{clc}
\hline \hline 分類 & \multicolumn{1}{c}{ 項目 } & 件数 $($ 件 $)$ \\
\hline 副作用に & 副作用の発現状況の確認 & 53 \\
関する情報 & 副作用による日常生活への支障の有無 & 12 \\
$(76$ 件 $)$ & 副作用発現の可能性とその対策 & 11 \\
\hline 治療薬に & 内服薬の服用・中止・再開の確認 & 4 \\
関する情報 & 他院および今までの治療薬の確認 & 4 \\
$(14$ 件 $)$ & 化学療法施行の確認 & 3 \\
& 投与・処方提案 & 3 \\
その他 & 薬の管理者 & 2 \\
患者情報 & 理解度確認 & 1 \\
$(10$ 件 $)$ & その他 & 7 \\
\hline
\end{tabular}

経障害の程度の確認といった「副作用の発現状況 の確認」が最も多く，ついで「副作用による日常 生活への支障の有無」や，過去の治療時の副作用 状況を確認したうえでの予測性嘔吐の可能性など といった「副作用発現の可能性とその対策」の順 であった。

また，薬剤師が医師に対してフィードバックを 行った「患者からの不安・訴えに関する情報提供」 の内訳を図 6 に示す。患者からの不安・訴えのう ち,「薬に関する事項」が全体の $65.0 \%$ を占め,「薬 以外の事項」は $35.0 \%$ であた。薬に関する事項 のうち，「副作用」に関する不安・訴えが $42.5 \%$ と最も多く, その内訳は, 薬に関する副作用全般,
悪心・嘔吐, 脱毛，下疮などであった。薬以外の 事項としては，病気に関する不安全般，体質への 不安，追加切除に対する不安などであった。

\section{3. 治療薬剂の理解度や患者の不安および薬剤師 外来の感想についての調査}

(1) アンケート結果

アンケート調査に同意が得られた外来がん患者 は62名（男性 10 名および女性 52 名）であった。 年齢は 55.6 13.2 歳であった。 がん種別では乳が ん患者が 50 名, 頭頸部がん患者が 12 名であった。 がん進行度別では, ステージ I が 15 名, II が 17 名, IIIが 8 名およびIVが 22 名であった. 薬剤師外来 


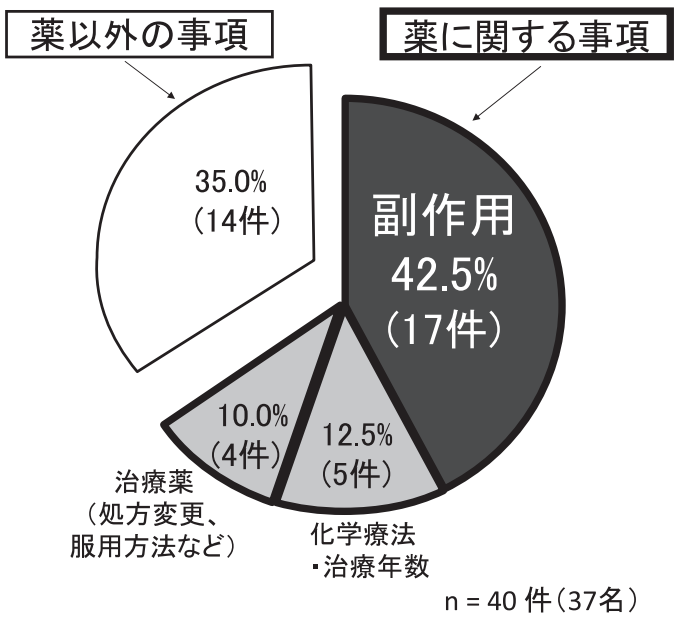

図 6 薬剤師が医師に対してフィードバックを 行った「患者からの不安・訴えに関する 情報提供」の内訳

受診回数は, 1 回が 46 名, 2 回が 13 名および 3 回が 3 名であり, 平均は $1.3 \pm 0.56$ 回であった. また, 表 1 において, 薬剤師が医師に対してフィー ドバックを行った「患者への服薬指導内容」の内 訳のうち, アンケート調査に同意が得られた外来 患者の割合は，「副作用」では $53.7 \%$,「薬歴・ア ドヒアランス」では $45.2 \%$ および「治療」では 60.8\%であった。同様に，表 2 の「過去の治療歴 に関する患者情報提供」の内訳のうち, 同割合に ついては,「副作用に関する情報」では $61.8 \%$,「治 療薬に関する情報」では $50.0 \%$ および「その他患
者情報」では $50.0 \%$ であった. いずれも,アンケー 卜調査に同意が得られた外来患者の割合に偏りは 認められなかった。

図 7 に薬剤師外来前後における治療薬剤に対 する理解度の変化を示す。「治療薬剤の理解度」, 「服用の重要性と投与スケジュールの理解」およ び「副作用の発現や予防法の理解」のそれぞれの 項目について, いずれも薬剂師外来受診後に患者 の理解度が有意に上昇した $(P<0.01)$.

薬剂師外来受診前後における治療に対する患者 の不安の変化を図 8 に示す。薬剂師外来受診前 の患者 62 名のうち，治療に対して「不安がある」 および「不安が少しある」と回答した患者は 50 名 $(80.6 \%)$ であり, 大部分の患者が何らかの不 安を持っていることがわかった。 そのうち, 薬凨 師外来受診後不安が「軽減した」および「少し軽 減した」と回答した患者は 44 名 $(88.0 \%)$ であっ た。なお，薬剂師外来受診前に不安がなかった 12 名については, 薬剤師外来受診後不安が「軽 減した」,「少し軽減した」および「変わらない」 のいずれかとなり,「少し不安になった」および「不 安になった」と回答した患者はいなかった。

薬剤師外来受診についての患者の感想について の調査では，「医師に聞きたいことは言えていると 思いますか」の設問では，「言えている」，「少し言 えてる」と回答した患者は $85.0 \%$ であった.内訳

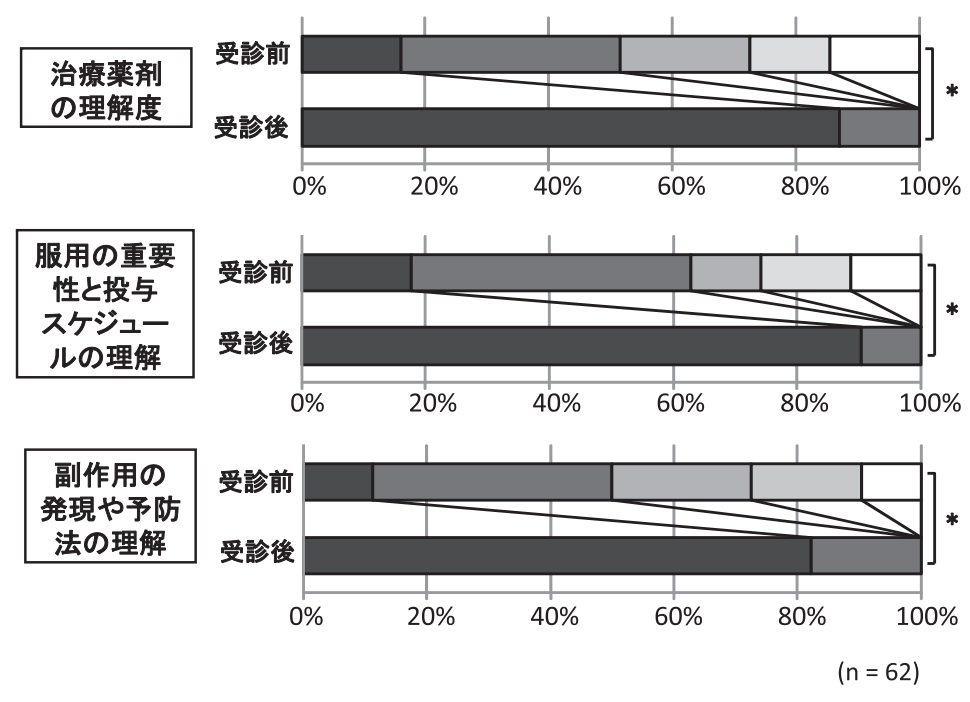

図 7 薬剂師外来受診前後における治療薬剤に対する理解度の変化

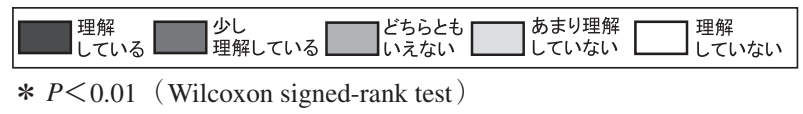




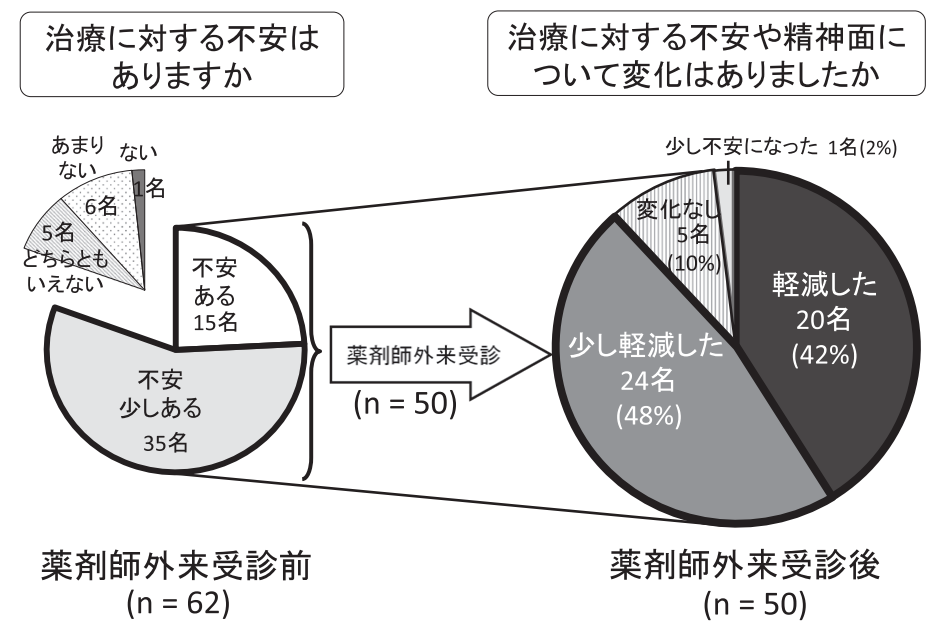

図 8 薬剤師外来受診前後における治療に対する患者の不安の変化

は乳がん患者 50 名中 44 名 $(88.0 \%)$ ，頭頸部がん 患者 12 名中 9 名（75.0\%）だった。また，がん進 行度別ではステージ I の患者 15 名中 13 名 $(86.7 \%)$, ステージ II の患者 17 名中 16 名（94.1\%)，ステー ジIIIの患者 8 名中 5 名（62.5\%）およびステージ IVの患者 22 名中 19 名（86.4\%）だった。「薬剤師 外来を受診してどうでしたか」の設問に対しは, 「大変良かった」，「良かった」と回答した割合が 100\%であった，回答率が 100\%であるため，回答 者に占める乳がん患者抒よび頭頸部がん患者の内 訳，がん進行度別の内訳は上述した患者人数と一 致した.「今後も薬剤師外来を受診したいですか」 の設問に対しは,「思う」,「少し思う」と回答した 割合は $93.0 \%$ でり, 内訳は乳がん患者 50 名中 48 名 $(96.0 \%)$, 頭頸部がん患者 12 名中 10 名 （83.3\%）だった。また，がん進行度別ではステー ジ I の患者 15 名中 14 名 $(93.3 \%)$ ， ステージ II の 患者 17 名中 16 名 $(94.1 \%)$ ， ステージ III の患者 8 名中 8 名 $(100 \%)$ およびステージIVの患者 22 名 の中 20 名 $(90.9 \%)$ だった。

（2）スコア化による不安軽減度の解析結果

薬剂師外来受診前の患者 62 名のうち, 治療に対 して「不安がある」および「不安が少しある」と 回答した患者 50 名を対象にスコア化による薬剂師 外来受診後の不安軽減度の解析を行った結果, 乳 がん患者では，頭頸部がん患者に比べて有意に不 安の軽減が認められた $(P<0.05)$ (図 9A)。乳が ん患者 39 名を対象にがん進行度別による解析を 行った結果, ステージ I ・ II の患者は, ステージIII ・
IV の患者に比べて有意に不安の軽減が認められた $(P<0.05)$ （図 9B）。乳がん患者の薬剂師外来受 診回数別による解析の結果, 初回受診患者と, 2 回以上の受診患者の両群間では, 不安軽減度につ いて有意な差は認められなかった（図 9C）.

\section{考察}

本研究では, 注射薬掞よび内服薬全ての抗がん 剂を対象とした当院薬剂師外来の役割とその評価 を行った．現在，注射薬の抗がん郕に対しては, 外来化学療法室において薬剤師が服薬指導を実施 している施設が増えてきている。一方, 内服薬抗 がん剤のみを服用する外来患者に対し, 薬剂師が 服薬指導を実施している施設は少ない.内服薬に ついては，抗がん剂特有の変則的な服用方法や投 与スケジュール，また，副作用の対処方法などに ついて, 患者自身の理解なくして, がん化学療法 を施行することは難しい．外来がん患者へは注射 薬抗がん剂とともに, 内服薬抗がん剂の服薬指導 が重要と考える. 当院薬剂師外来では, 注射薬の みならず内服薬も対象としているため, 外来がん 患者の薬物療法を網羅できていると考える(図1). しかし, 現在, 医師からの依頼は, 乳腺センター と頭頸部腫瘍センターの 2 診療科に留まっている ため, 今後は, 診療科の拡大が課題と言える.

薬剤師は患者に対し, 薬歴・アドヒアランスを 確認したり，副作用および治療に関することなど 広範囲にわたり服薬指導を行っている（表 1 ）。 
指導内容のうち, 副作用の種類や発現時期および, その対策方法などといった副作用に関する指導が 最も多いことが明らかになった，具体的には，悪 心・嘔吐，末梢神経障害や手足症候群などの発現 とその時期，悪心・嘔吐対策薬などについての説 明であった。このことから, 薬剤師外来受診後の 治療薬剂の理解, 服用の重要性と投与スケジュー ルの理解，および副作用の発現や予防法の理解に 繋がったと考えられる (図 7)。窪田ら, ${ }^{6}$ 石川ら は，主に注射薬抗がん剂治療を受けた外来化学療 法施行患者を対象に, 薬剂師による説明の有用性 について報告している。今回の上記結果は，これ らの報告と一致した。しかし，当院薬剤師外来は 注射薬抗がん剂のみならず内服薬も対象としてい る点でこれら報告の対象患者と大きく異なる．今 回，外来がん患者の薬物療法を網羅することが可 能な当院の薬剂師外来において，その有用性を示 すことができたことの意義は大きいと考える.

図 8 に示すように, 薬剤師外来受診前に, 62 名中 50 名 $(80.6 \%$ ）の患者が治療に対して何ら かの不安があると回答していた。しかし，医師へ のフィードバック内容の解析では, 薬剂師に不安 を訴えている患者は 33.3\% (111名中 37名)であっ た（図 5)。このことから，多くのがん患者は治 療前には不安を抱えているにもかかわらず，薬剤 師に不安を訴える患者は 3 割と少ないことがわ かった，従って，薬剤師はこれらのことを踏まえ て服薬指導していくことが大切であると考える.

一方, 薬剤師外来受診後では, 受診前に不安を もっていた患者 50 名のうち 44 名 $(88.0 \%)$ が不 安の軽減を認めた（図 8)。薬骫師による副作用 等についての服薬指導や薬剤管理指導が患者の不 安軽減に繋がった可能性が考えられる。このこと については, 北澤ら ${ }^{8)}$ も同様の考えを示している.

スコア化による不安軽減度の解析結果から, 乳 がん患者は頭頸部がん患者に比べて不安の軽減度 が大きいことが明らかになった（図 9A）。さら に乳がん患者では，ステージ I ・ II の早期がん患 者で不安の軽減度が大きいことが明らかになった (図9B)。乳がんや頭頸部がんは，手術において 容貌の変化や機能障害による影響が大きく，大き な精神的衝撃を与えることが知られている. ${ }^{9}$ 乳
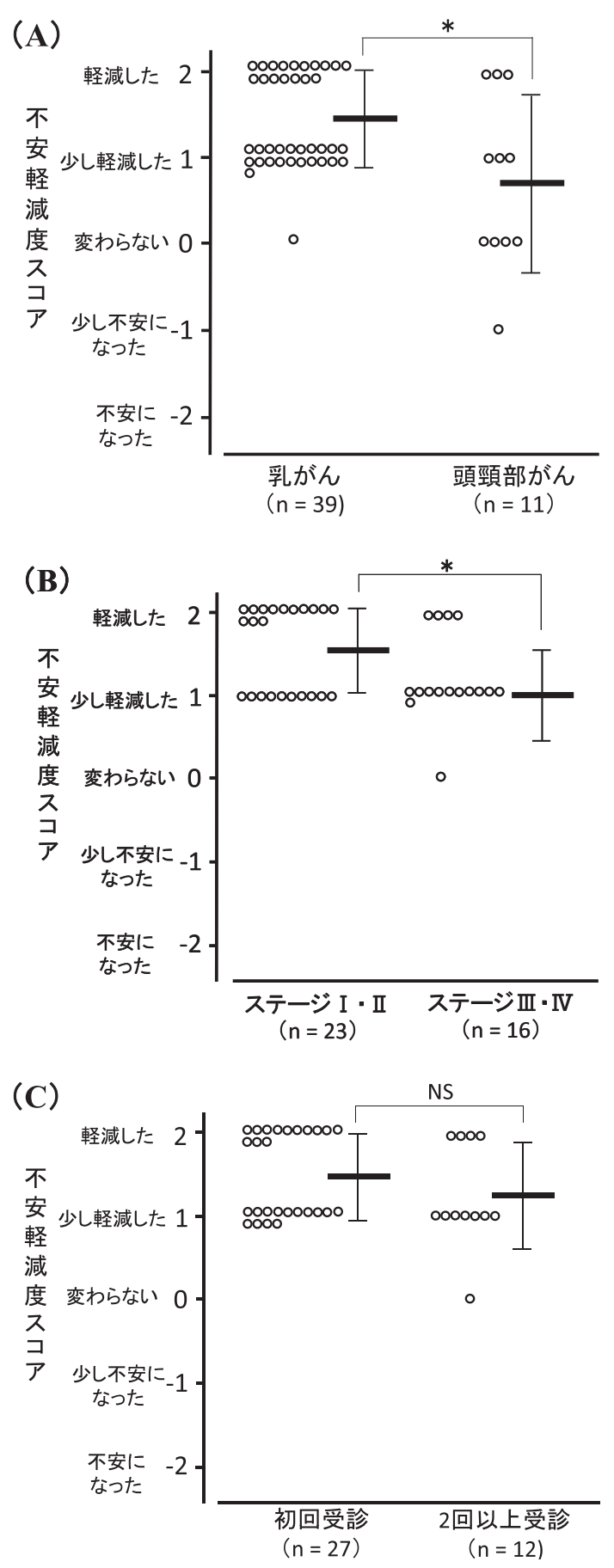

図 9 患者背景別の不安軽減度の比較

(A) がん種別比較

（B）乳がん患者のがん進行度別比較

(C) 乳がん患者の薬剂師外来受診回数別比較

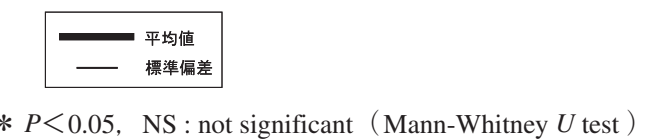

がん治療における薬物療法は, 術後補助療法や再 発・転移乳がんの治療で多く使用されているが, 頭頸部がん治療は手術および放射線治療が中心と なり薬物療法の寄与が小さい。薬物療法が多く選 
択される乳がん患者において，薬剤師による介入 が不安の軽減に結び付いたと考えられる。図 9A における乳がん患者 39 名中, 薬荗師外来受診後 に，不安の変化が「変わらない」と回答した患者 は 1 名であった。当該患者については, 内服抗が 几剤から注射薬へ切り替えになる際，とくに不安 を強く感じている症例であった。このような症例 では，薬剤に関する疑問や不安の解消を図るため に，今後より一層，丁寧な服薬指導を心掛ける必 要があると考える。 また，がんのステージ別調査 では，ステージ I ・ II の患者とステージIII ・IVの 乳がん患者に扔いて不安に差がないとの報告 ${ }^{5)}$ が あるが，今回，ステージ I ・II の乳がん患者はス テージIII・IV の患者に比べ不安軽減度が大きい結 果であった. 当院の薬剤師外来はがん化学療法の 早期段階から介入するため，ステージ I ・ II の患 者で不安軽減につながった可能性が考えられる.

薬䯇師は医師へ対して，患者への指導内容，患 者の過去の治療歴に関する患者情報提供や患者か らの不安・訴えに関する情報をフィードバックし ていた（図 5)。過去の治療歴に関する患者情報 提供については，副作用に関する情報提供が多い ことが明らかになった（表 2)。とくにレジメン が変更になった患者に対しては，過去の抗がん剂 治療時の副作用発現状況の確認を行い, これから の治療における副作用発現の予測性について情報 提供を行っていた。これら副作用に関する患者情 報を中心に医師へフィードバックすることによ り, 薬剂師外来は医師への薬物療法支援に役立っ ている可能性が考えられる。 しかし, 今回, 薬剤 師から医師への処方提案は 3 件と少なかった。こ れは, 当院の薬剂師外来の受診回数は平均 1.3 回 であり，多くの患者が継続的な受診をしていない ために，薬剤師は，副作用や治療に関するモニ夕 リングを十分にできていないことが原因と考え る. な押，医師への処方提案 3 件については，提 案後の変更・追加は認められなかった.

当院の薬剤師外来では，入院患者に対する服薬 指導のように継続的に薬学的介入を行うことが今 後の課題と言える. しかし, 今回, 薬剤師外来を 初めて受診した患者は, 2 回以上受診した患者と比 ベ不安軽減度については差が見られなかった（図
9C). このことから，とくに薬剤師外来を受診する 患者に対する初回の薬学的介入が重要と考える.

以上のことから, 当院における外来がん患者に 対する薬剤師外来の役割は, 治療薬剂の理解向上 と治療に対する不安を軽減させることで, 患者が 安心してがん治療に参加することへの支援を担っ ていることが示唆された，また，副作用などに関 する患者情報を医師へフィードバックすること で，外来がん患者の薬物療法の支援に役立ってい ると考えられる。

\section{引用文献}

1）山村恵子, 薬剤師外来 “ワルファリン教室” 科学 的業務の構築・服薬指導の成果を数值で評価す る, 東京都病院薬剤師会雑誌, 2005, 54, 269-274.

2) Hasegawa M, Takagi K, Shimokata K, Byrd HJ, Nabeshima T, Evaluation of "Bronchial Asthma Pharmaceutical Care Clinic for Outpatients" Run by Pharmacists at Nagoya University Hospital, 医療薬 学, 2006, 32, 1038-1043.

3）今村牧夫, 名倉弘哲, 武本千恵, 外来がん患者に 対する薬剤師外来の有用性の検討, 医療薬学, 2010, 36, 85-98.

4）前勇太郎, 横川高志, 川上和宜, 八木奈央, 末永 光邦, 篠崎英司, 松坂 諭, 水沼信之, 濱 敏弘, XELOX療法に抢ける薬郕師外来の有用性, 医療 薬学, 2011, 37, 611-615.

5）福江真由美, 内富庸介, 石田百合, 久賀谷亮, 皆川 英明, 山脇成人, 乳がん患者の感情状態とその要 因一外来通院患者の調查より一, 臨床精神医学, 1995, 24, 1359-1365.

6）窪田和弘, 藤巻眞弓, 大久保吉弘, 花岡孝臣, 外来 がん化学療法に扔ける薬剤師のアプローチ一薬 剤師が説明にかかわる有効性一, 日本病院薬剤 師会雑誌, 2007, 43, 387-389.

7）石川元章, 中神真寿美, 町支優和, 佐藤勝紀, 鈴木 善貴, 山岡恭子, 外来がん化学療法における説明 に関する評価と課題, 日本病院薬剤師会雑誌, 2008, 44, 1269-1273.

8）北澤文章, 安部敏生, 上田久美, 村頭 智, 高良 恒史, 横山照由, 杉井彦文, がん化学療法施行患 者の精神面に及ぼす薬学的ケアの影響, 医療薬 学, 2010, 36, 37-43.

9）山脇成人, “サイコオンコロジーがん医療にお ける心の医学”, 診療新社, 大阪, 1997, pp.172-174. 